The Journal of Public Space

ISSN 2206-9658

2018 | Vol. 3 n. 2

https://www.journalpublicspace.org

Architecture

\title{
Investing in Spaces: Luxury, Benevolence or Business?
}

Nabila Alibhai

InCOMMONS, Kenya

nabila@in-commons.com

with

\section{Elizabeth Thys}

Massachusetts Institute of Technology (MIT), United States of America

liz@limeshift.com

\begin{abstract}
This paper highlights the use of spatial transformation to shift the way people experience and engage with community. In essence, physical spaces can make people feel safe, well and like they belong. Moreover, they can infuse purpose into their habitual public and work-life experience. The examples shared include working with the Yale School of Management to help students reflect on and visibly communicate their role as leaders in business and society; the property development company Broder using public art to respectfully build a relationship with a neighborhood they are investing in; YouTube using the process of art creation to celebrate and communicate diversity in the workplace and lastly a public private partnership that brought together the Government, civil society and the private sector to address the erosion of trust and fear as a result of violent extremism in Kenya through a public art installation called Colour in Faith. Nabila Alibhai and her collaborators work to shift culture through investing in the transformation of spaces using art and urban design.
\end{abstract}

Keywords: public spaces, corporate spaces, employee engagement, values

To cite this article:

Alibhai, N. (2018). Investing in Spaces: Luxury, Benevolence or Business? The Journal of Public Space, 3(2), 75-96, DOI I0.3289I/jps.v3i2.IIII0

This article has been accepted for publication in The Journal of Public Space. Please see the Editorial Policies under the 'About' section of the journal website for further information.

This work is licensed under a Creative Commons Attribution - Non Commercial 4.0 International License https://creativecommons.org/licenses/by-nc/4.0/ 
Investing in Spaces: Luxury, Benevolence or Business?

"What is it that makes us move forward if it isn't happiness, and vision and solidarity."

This was how I began my talk to more than one hundred Corporate Executives from Godrej articulating that investing in spaces would be a great idea. Why start a conversation about public spaces with a conversation about human wellness and behaviour? The answer is obvious to most practitioners working on the design and planning of public spaces but not as obvious to corporations.

Investing in spaces, ties people together through a common experience. When designed deliberately, this investment can provide the optimum environment in which to thrive. For each community, the definition of an optimum environment will be different. For some it'll be an experience of joy, or being prompted by space to interact with the people with whom they share a joint purpose, or having visual reminders of that purpose, or simply having peace and quiet that will allow them to create.

Whatever it is - this psycho-social environment can be thoughtfully designed to reinforce positive cultural traits and to invoke a sense of community and shared identity. Each one of the examples below takes a cultural trait identified by a community - corporate or public - as aspirational, and brings that culture to life through thoughtfully transforming the space and involving the community in the creation of the space. The latter element, the process of co-creation, plays the important function of reinforcing belonging, and agency. Belonging is in fact an critical pre-requisite to participating in the improvement, cohesion and productivity of any community.

Our work with corporate communities in particular has shown that investing in the social values and notions of pleasure in the workplace experience manifest higher employee and client engagement. Examples presented in this paper will demonstrate how spaces address the gaping problem of employee engagement and highlight the innovative ways in which this concern has been approached and remedied.

In addressing the issue of employee engagement, we first analyzed the top factors that have been shown to improve engagement. Research points to the following as the top four issues to improve engagement: Role Design, Organizational Identity, Career Ladders and Community.

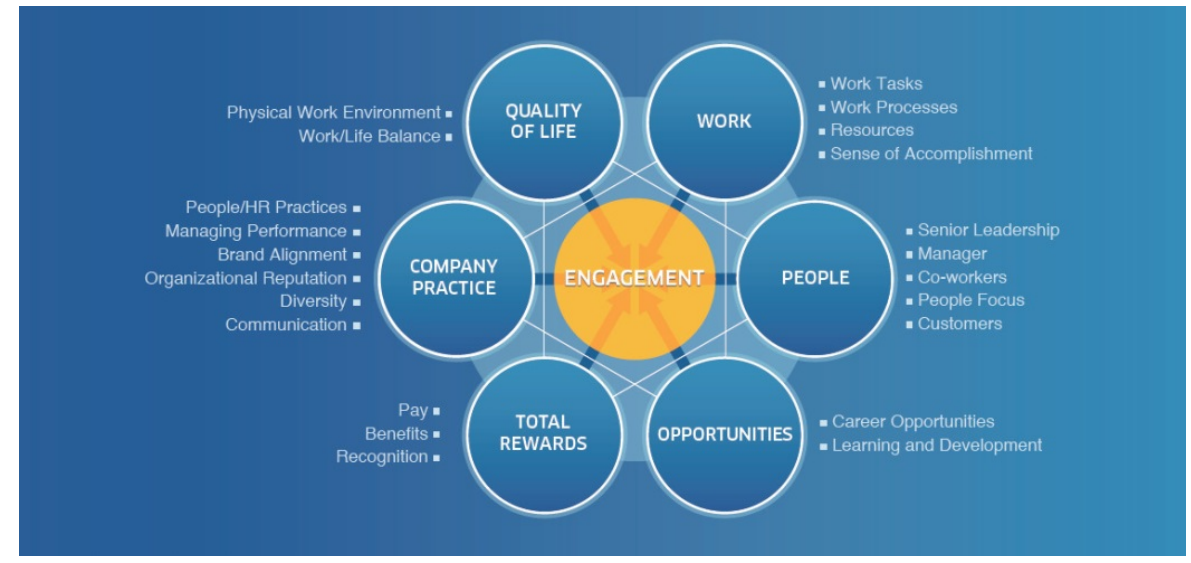

Figure I. Drivers of Employee Engagement.

Source: "Employee Engagement in Theory and Practice: Why Should You Care About Employee Engagement?" (2015) Microedge.com. MicroEdge, LLC. 
COMPANY PROCESS

Role design

Organizational identity

Career ladders

Community

Resource planning

Leadership

Compensation

Governance processes

Performance review
TOTAL MOTIVATION FACTOR

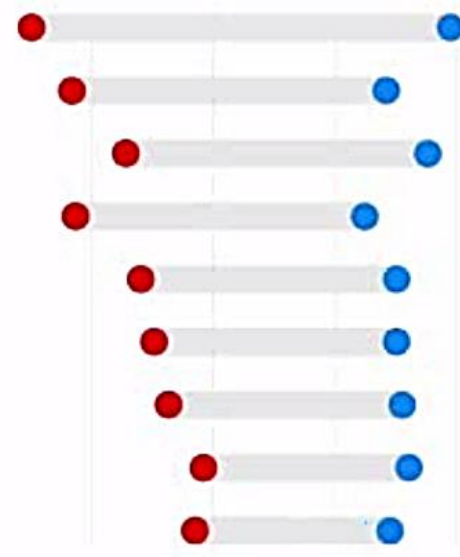

$-100$

Figure 2. Employee Motivation Ranked by Company Process.

Source: McGregor, Lindsay, and Neel Doshi. "How Company Culture Shapes Employee Motivation." Harvard Business Review, 20 Apr. 2016.

Through this lens, we view Role Design as more than the tasks assigned to the employee. Effective Role Design means an individual has a clear purpose within a collective context. It helps to set boundaries, empowers individuals within the collective and creates ownership by building out spheres of influence.

Focusing on improving role identity, our spatial transformation process influences both Organizational Identity and Community. When we align individual and organizational values and give people a sense of ownership in the company, employee engagement drastically improves.

Spatial design is not just about public good and benevolence but in fact is good business. In the case studies presented here we see aesthetic intervention in spaces, having the following effects:

$\checkmark$ Providing a gesture or exchange, a feeling of being part of something greater.

$\checkmark$ Visually describing a higher aspiration.

$\checkmark$ Enhancing employee wellness, motivation, integration, retention.

The company limeSHIFT has worked on several spatial interventions focused on helping employees connect with their own senses of purpose and connect with the people and environment around them, connecting people, place and purpose. The most relevant ones, described in the following pages, are:

- Espejismo. Reinforcing leadership in business and society, by artist Yazmany Arboleda

- Responsible development in a new neighborhood, by artists Ellen Rutt and Patrick Ethen

- Integrating and representing a diverse team, by artis Miguel Arzabe

We present also Colour in Faith - http://www.colourinfaith.com/ - a project of inCOMMONS, which invited religious communities to paint their sacred spaces in "optimistic yellow." 


\section{CONCLUSION}

Investing in space means working through the complexities of political, economic, social, and cultural interests. This paper has shown that in our present era of the modern world economy, it makes corporate sense to invest in and sustain local forms and practices of social, economic, and cultural "luxury." Sustainable business presence, practice, and profits relies upon a careful understanding that clients perceive luxury also as social wellbeing. In each case study above, the projects stakeholders were enriched in a variety of ways: their client's knowledge, ideas and practices for smart investment and both the stakeholder and the client produced new understandings of how corporate relations should be reconsidered to suit this investment approach.

In each case a basic process was employed:

I Identifying the aspirational culture with the community and it's leadership;

2 Designing an experience with an artist and community builder in order to meet these objectives,

3 Guiding participants through a applied process that allowed them to practice the values;

4 Culminating the process by completing a spatial transformation created by applying behaviors that reinforce specific cultural traits e.g. collaboration, participation, creativity.

What remains evident is that investments in spaces are evolving to enable corporate and non-corporate communities to deliver on luxury, benevolence and business.

\section{References}

Interview with Pastor Onesmus Chakaya Keverenge, PAG Makina Church, Kibera. 6 February 2018. Availabe at: https://www.linkedin.com/pulse/want-improve-employeeengagement-think-people-place-purpose-thys/

inCOMMONS is a company that develops and invigorates public spaces and builds collective leadership. inCOMMONS's New York-based sister company, limeSHIFT, uses the same principles and embeds artists into workplaces to make them more happy, purposeful and creative. Their work has been featured in a 2017-published TED Talk, lectured about at Harvard University and the Massachusetts Institute for Technology and featured in notable press outlets including the New York Times, The Guardian, BBC, Al-Jazeera, DOMUS Magazine, the Smithsonian Magazine, among others.

http://limeshift.com/

http://www.in-commons.com/ 


\section{Espejismo. Reinforcing leadership in business and society}

Client:Yale School of Management (SOM)

Artist:Yazmany Arboleda

The mission of the Yale School of Management is to educate leaders for business and society. The following three objectives shape how Yale SOM puts its mission into practice:

I. Be the business school that is most integrated with its home university

2. Be the most distinctively global U.S. business school

3. Be recognized as the best source of elevated leaders for all sectors and regions. limeSHIFT worked to activate SOM's mission through art.

The scope of work, defined through interviews with the Dean, several professors and the student community, was to create an interactive experience where diverse groups are called on to lead, create and participate. The art piece was to address the following ideas:

- The value of social impact for business

- Understanding the significance of the individual within the whole

- SOM's role within the Yale community and globally as a thought leader

- Authentic engagement among Yale SOM students

- More creativity and freedom within the SOM student experience

- The relationship between physical and social and the need to create a safe space for open dialogue.

Yale School of Management launched ESPEJISMO:A Festival of Borrowed Reflections, an artistic collaboration with Colombian-American artist and limeSHIFT cofounder Yazmany Arboleda.
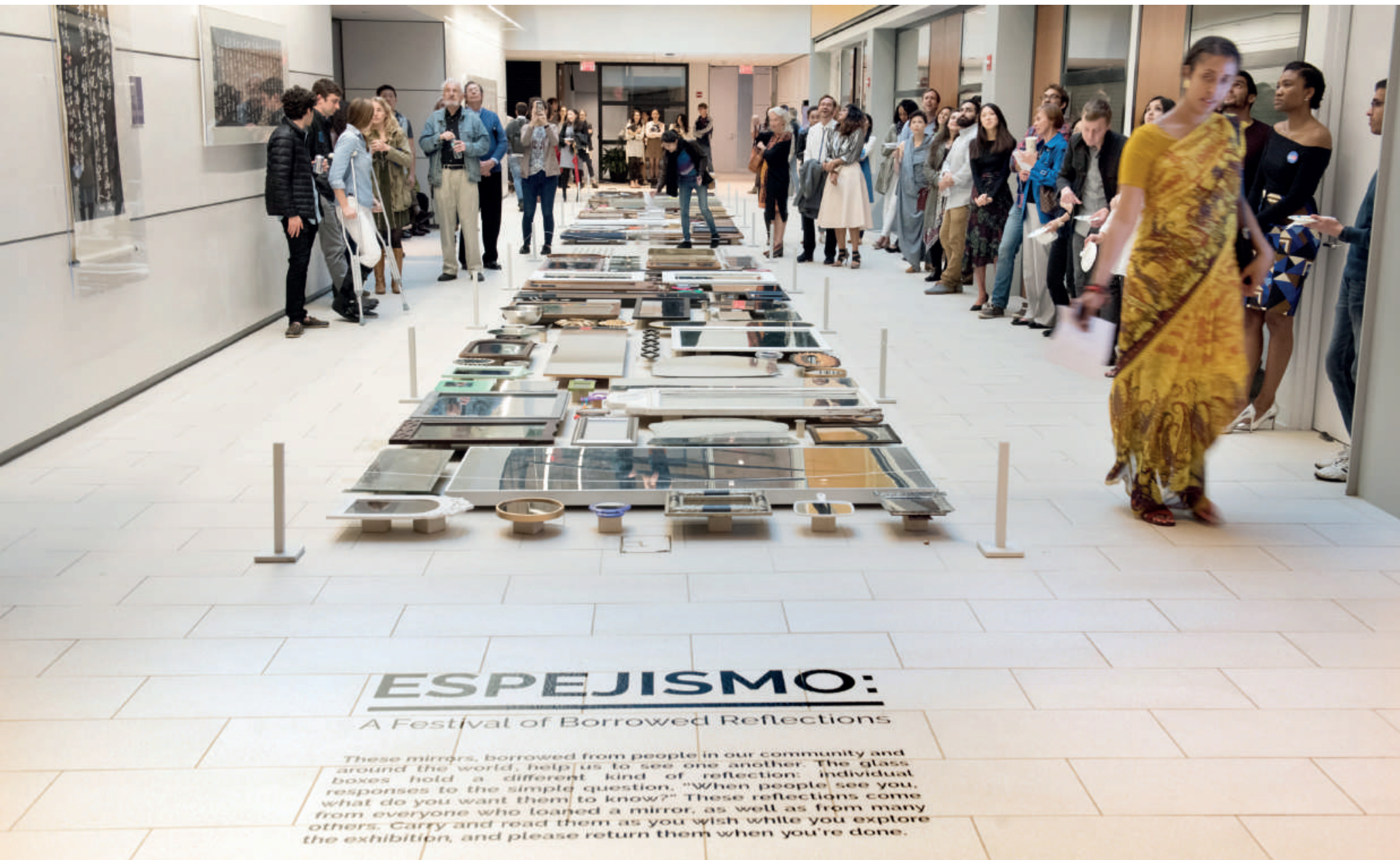

79 | The Journal of Public Space, 3 (2), 2018 | ISSN 2206-9658

City Space Architecture / UN-Habitat 


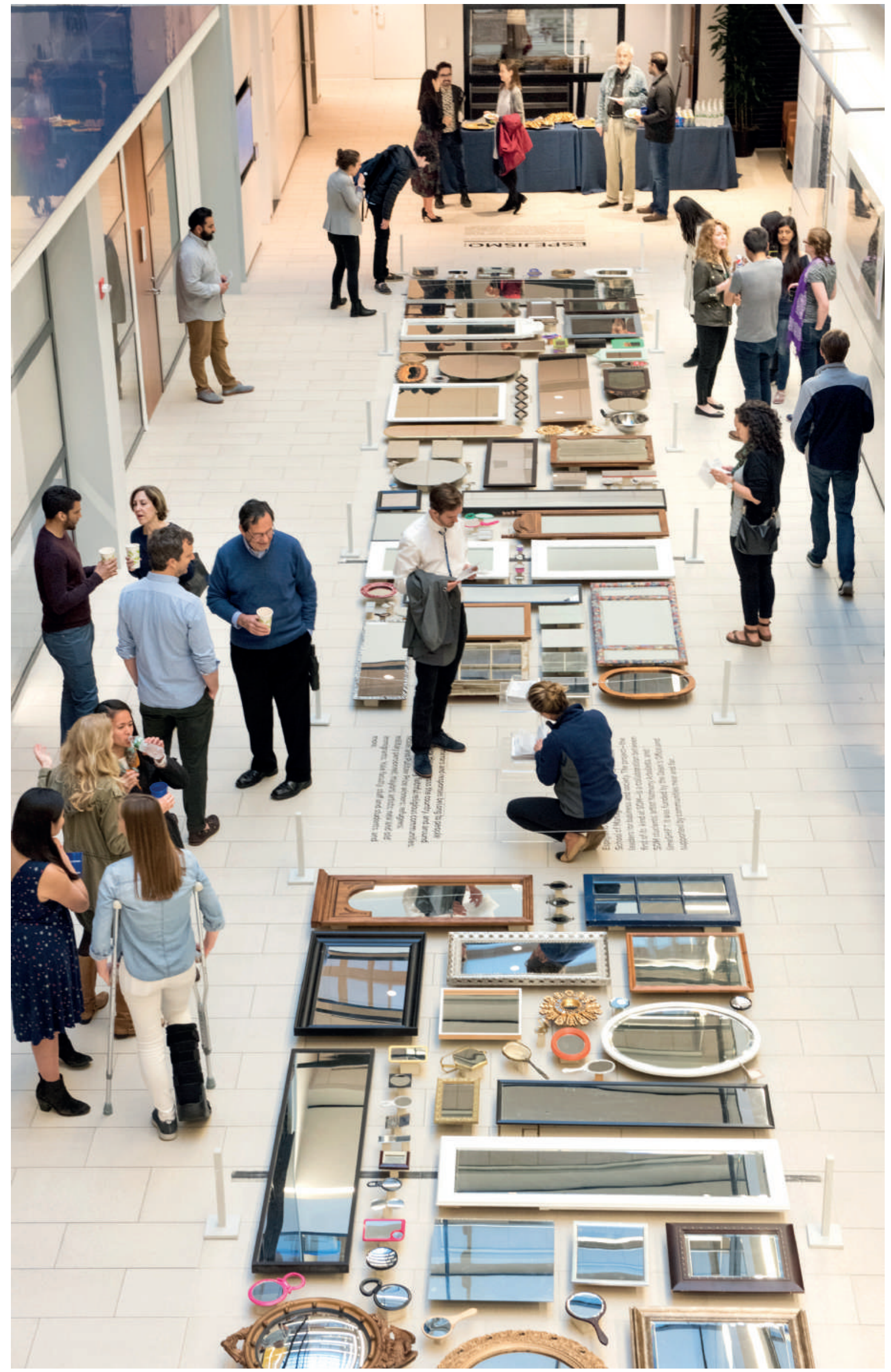

80 | The Journal of Public Space, 3 (2), 2018 | ISSN 2206-9658

City Space Architecture / UN-Habitat 


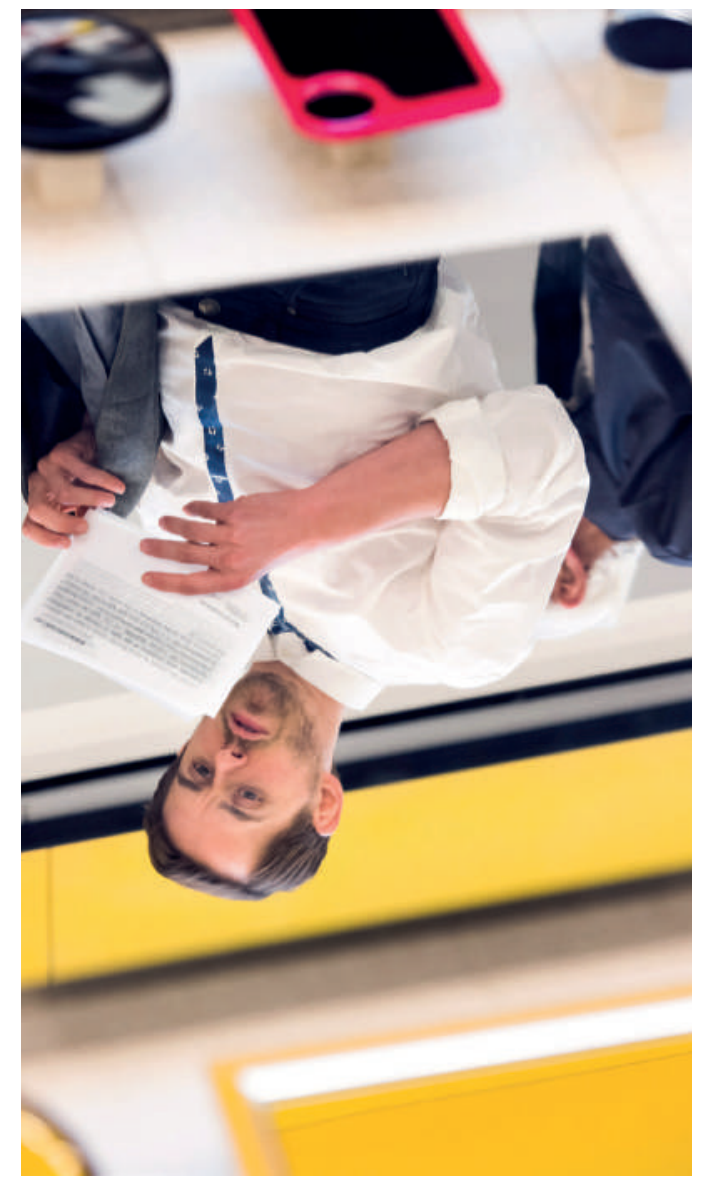

The art manifested as a digital platform and physical installation. Espejismo filled the Bekenstein Atrium of the Yale School of Management with mirrors borrowed from Yale students, New Haven residents, and communities around the world.

Laid across the floor of the atrium, the mirrors transformed the space into a garden of reflections that invited viewers to consider the perspectives of others. Eight more faculties were inspired to join the effort, along with 16 local philanthropic organizations.

The students sourced over 300 reflections and garnered over 200 mirrors in one week. The event was seen by hundreds of people in person, and thousands more online and was highlighted for it's message and impact in the regional press.

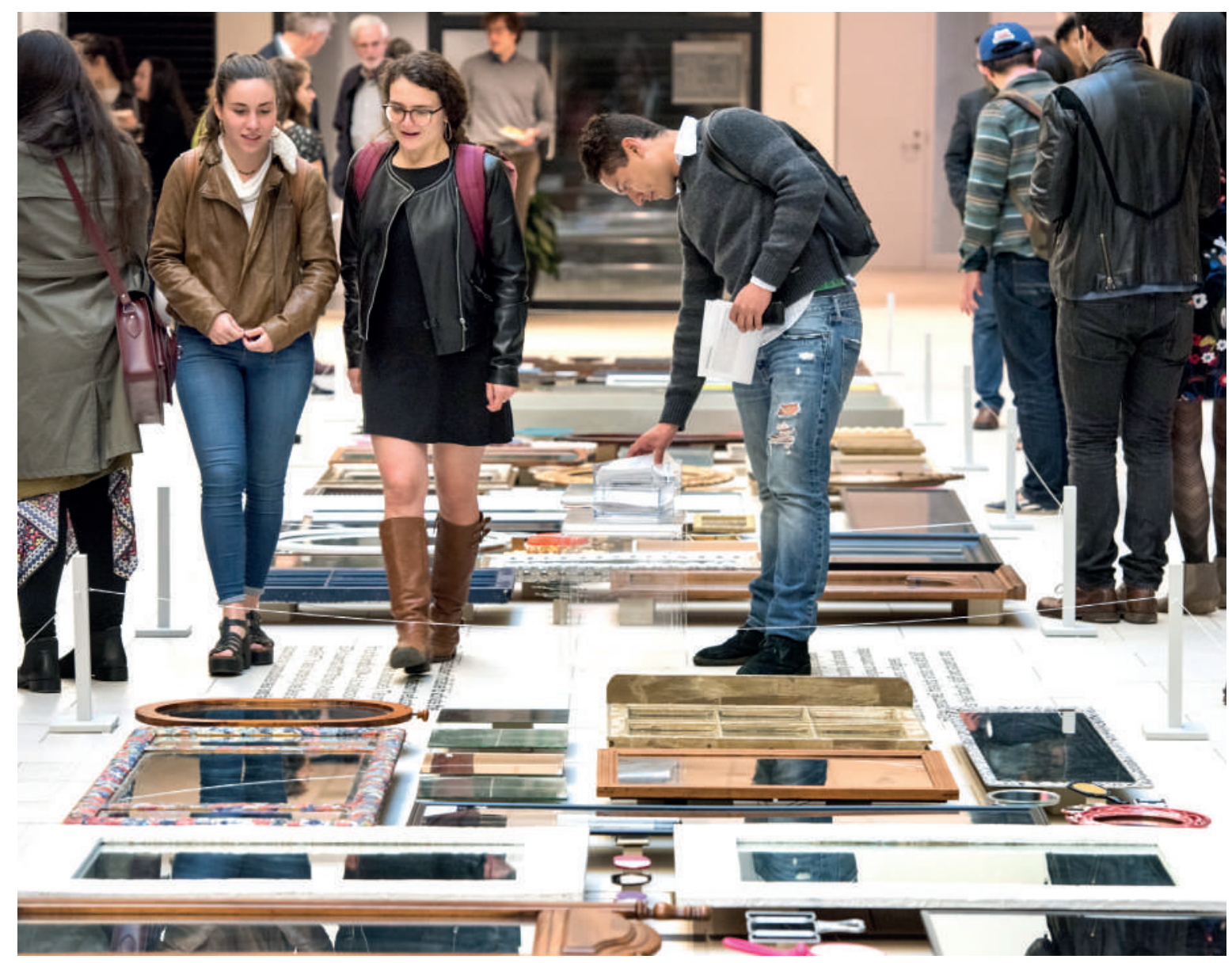

8I | The Journal of Public Space, 3 (2), 2018 | ISSN 2206-9658 City Space Architecture / UN-Habitat 


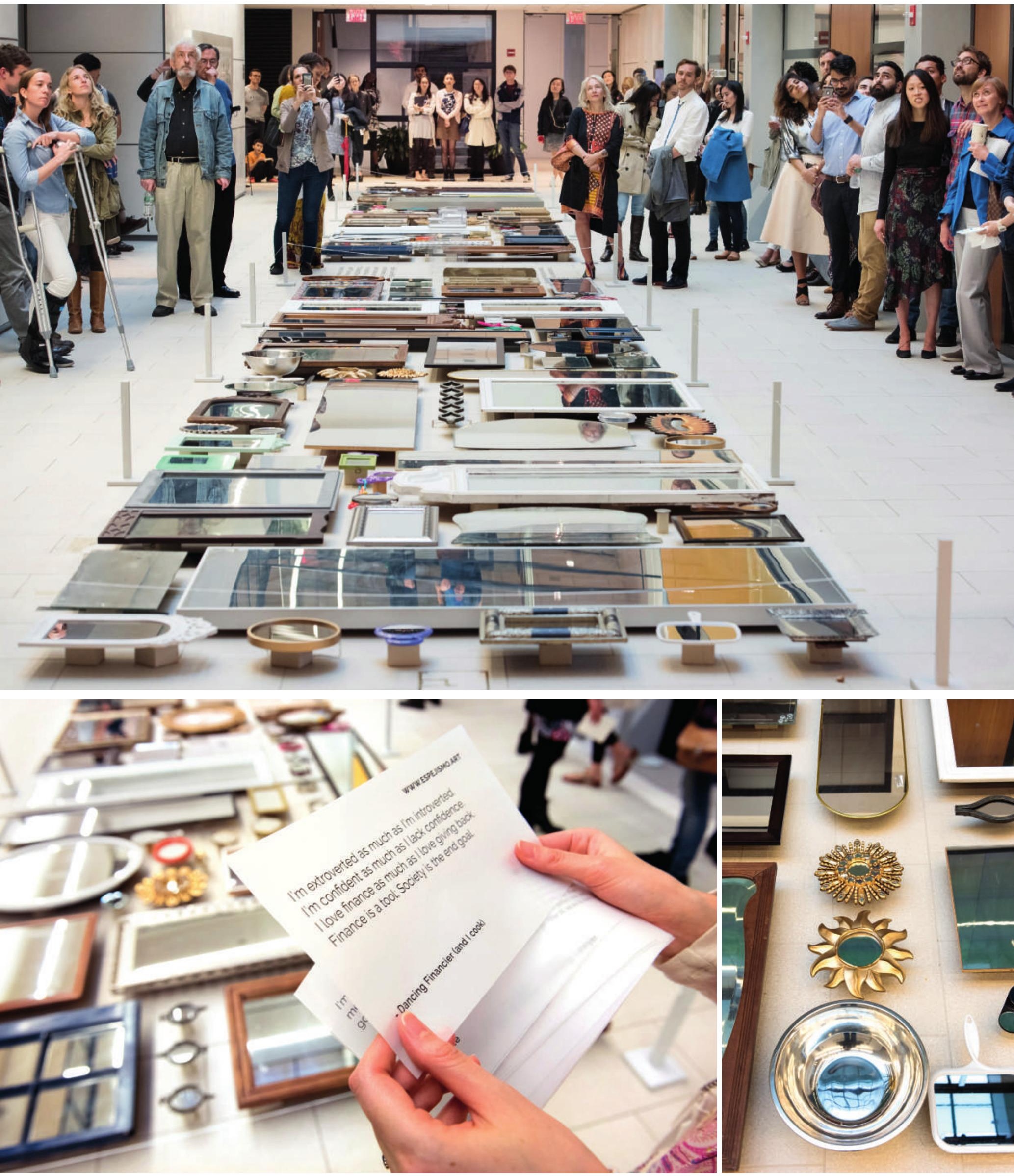

82 | The Journal of Public Space, 3 (2), 2018 | ISSN 2206-9658

City Space Architecture / UN-Habitat 
Nabila Alibhai with Elizabeth Thys
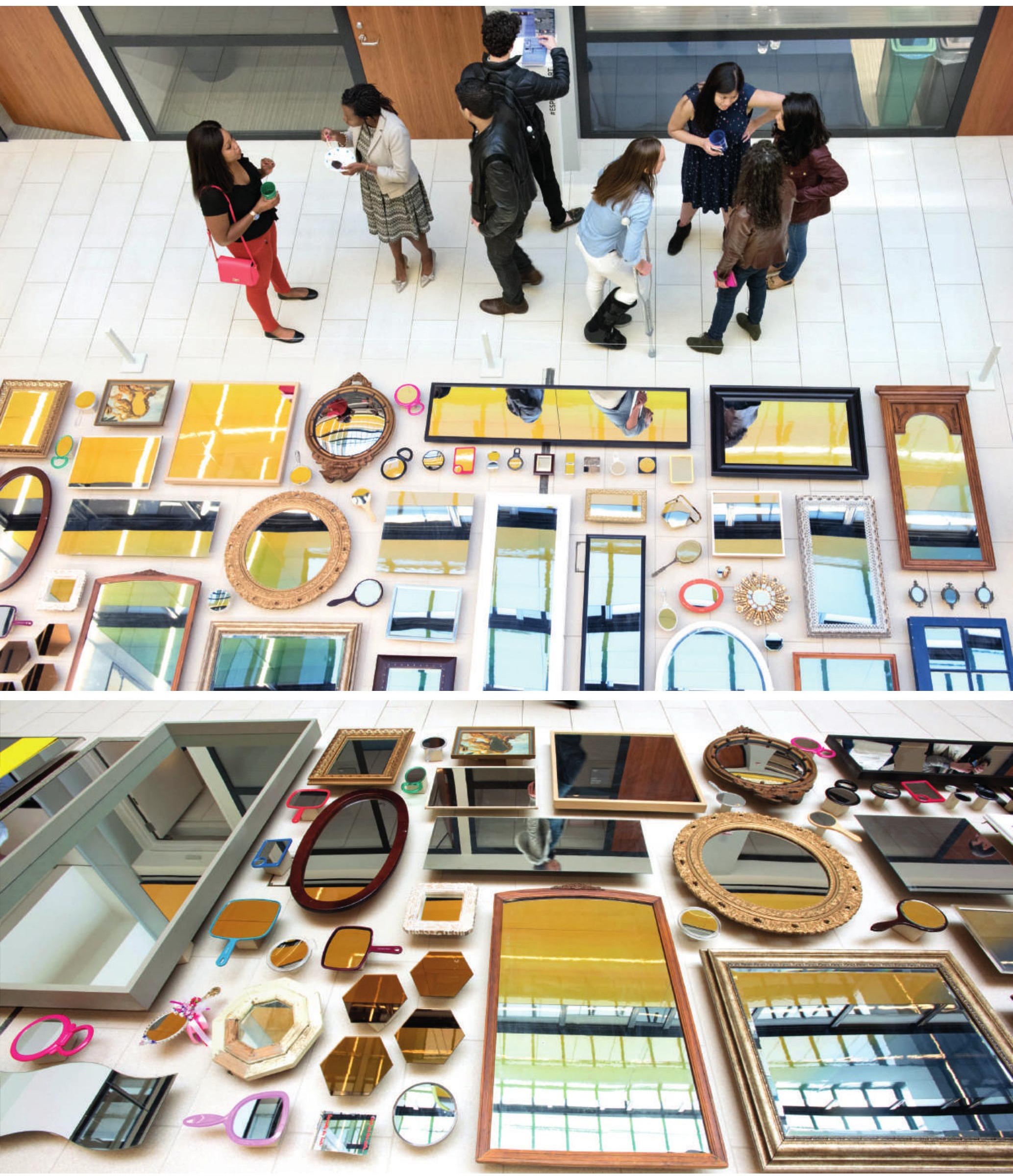

83 The Journal of Public Space, 3 (2), 2018 | ISSN 2206-9658 
Investing in Spaces: Luxury, Benevolence or Business?
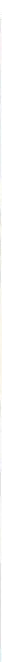

9

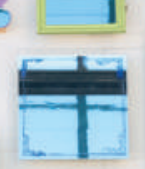

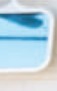
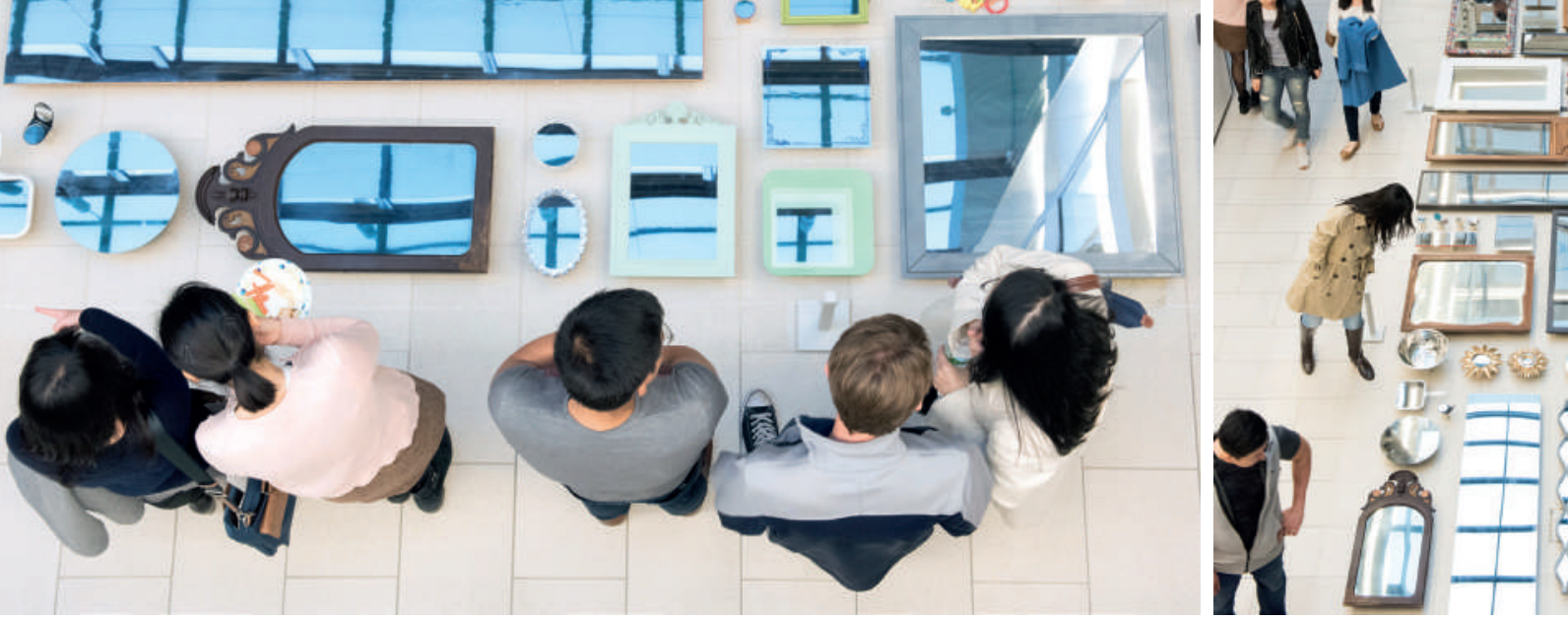

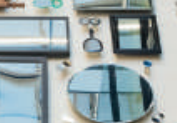
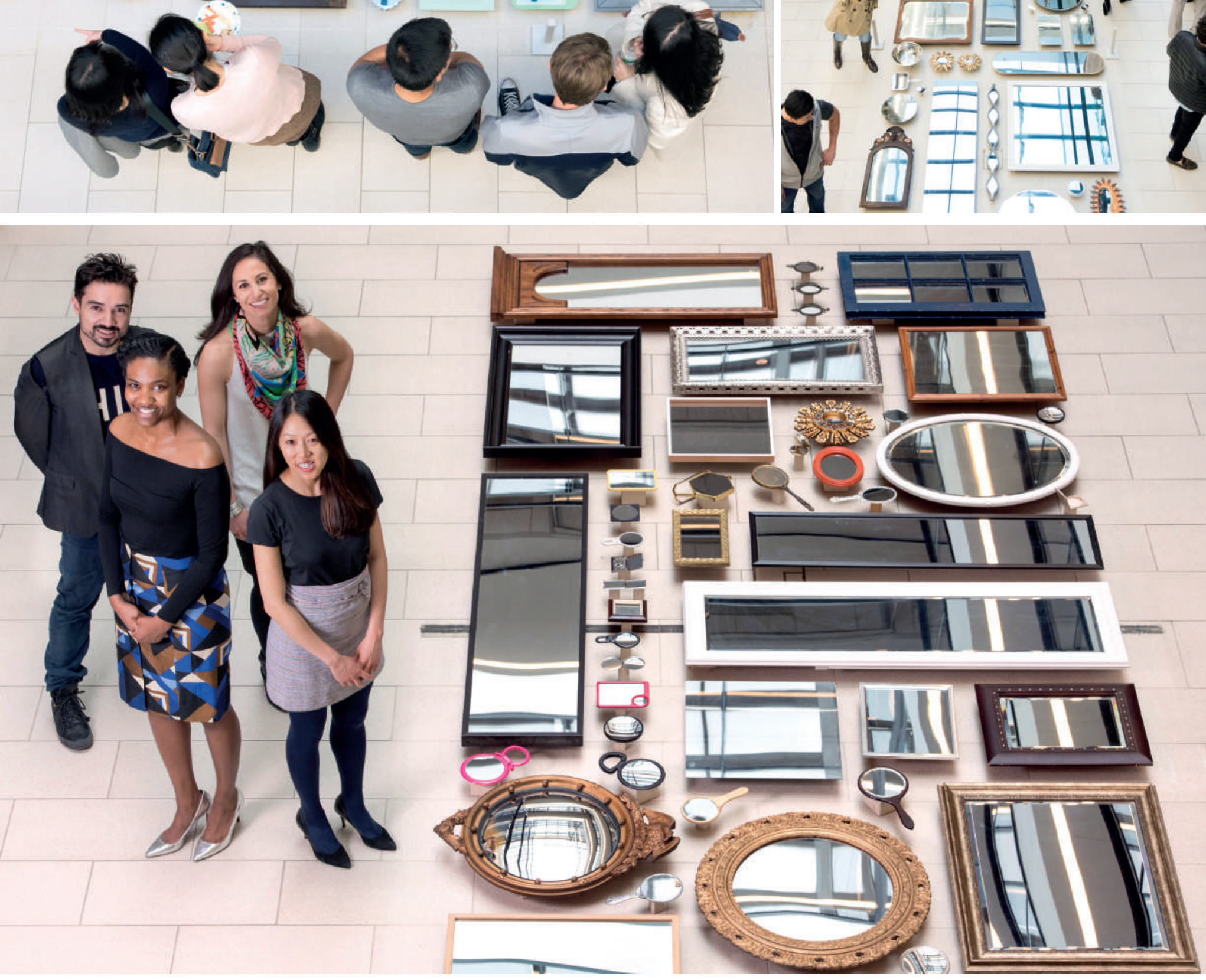

84 | The Journal of Public Space, 3 (2), 2018 | ISSN 2206-9658

City Space Architecture / UN-Habitat 
Investing in Spaces: Luxury, Benevolence or Business?
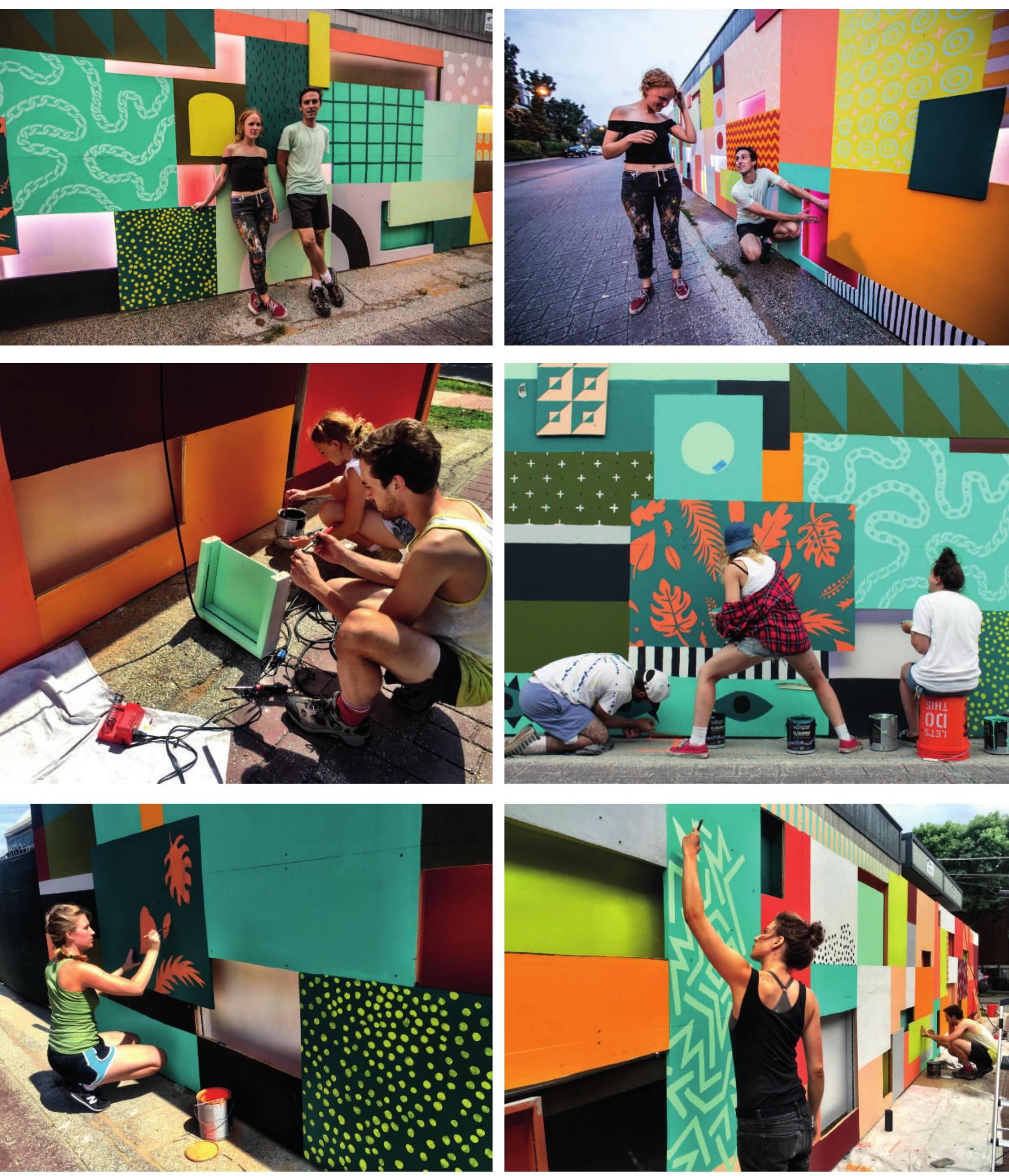

86 | The Journal of Public Space, 3 (2), 2018 | ISSN 2206-9658

City Space Architecture / UN-Habitat 
Investing in Spaces: Luxury, Benevolence or Business?

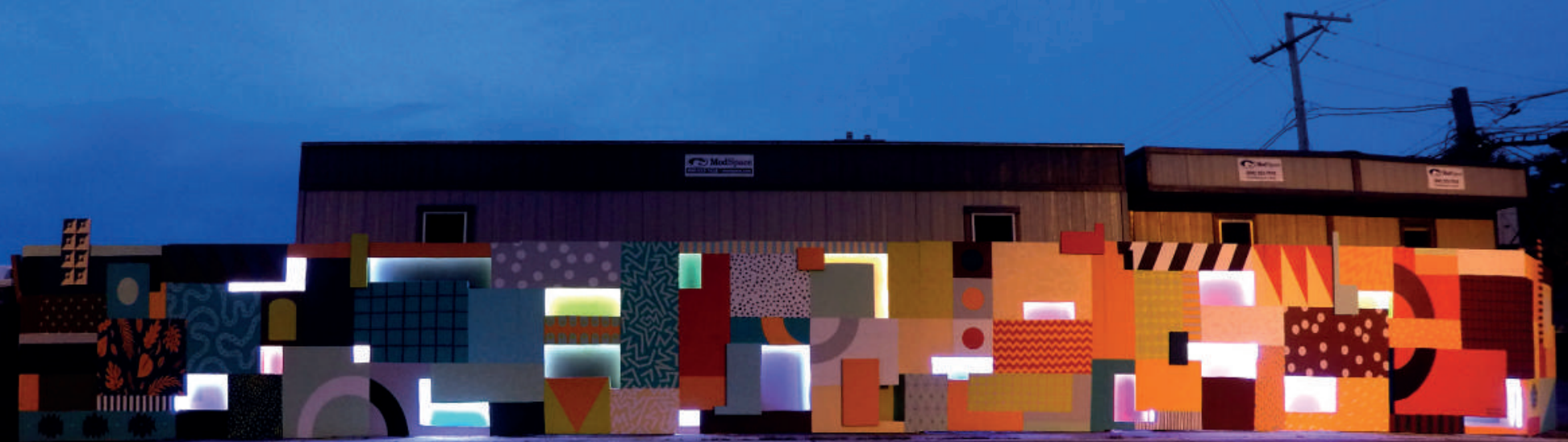

88 | The Journal of Public Space, 3 (2), 2018 | ISSN 2206-9658

City Space Architecture / UN-Habitat 


\section{Integrating and representing a diverse team}

Client:YouTube

Artist: Miguel Arzabe

YouTube was looking for a way to integrate and represent their diverse team. They were interested in creating an opportunity for team members to engage with each other in a creative and authentic way. They were also looking for a way to activate an underutilized common space.

Invesment in diversity isn't just good for the world, it is good for business. Deloitte did a study that showed that teams that have more gender diversity are 15 times more effective, and teams that are ethnically diverse are 35 times more effective.

limeSHIFT was challenged with how to create integration in the workspace. limeSHIFT curated a selection of local artists from San Francisco and the bay area that matched YouTube's brief. The company wanted to collaborate with an artist whose practice embodied inclusivity, collaboration, and positivity. It was also important that the artist have a meaningful trajectory already.

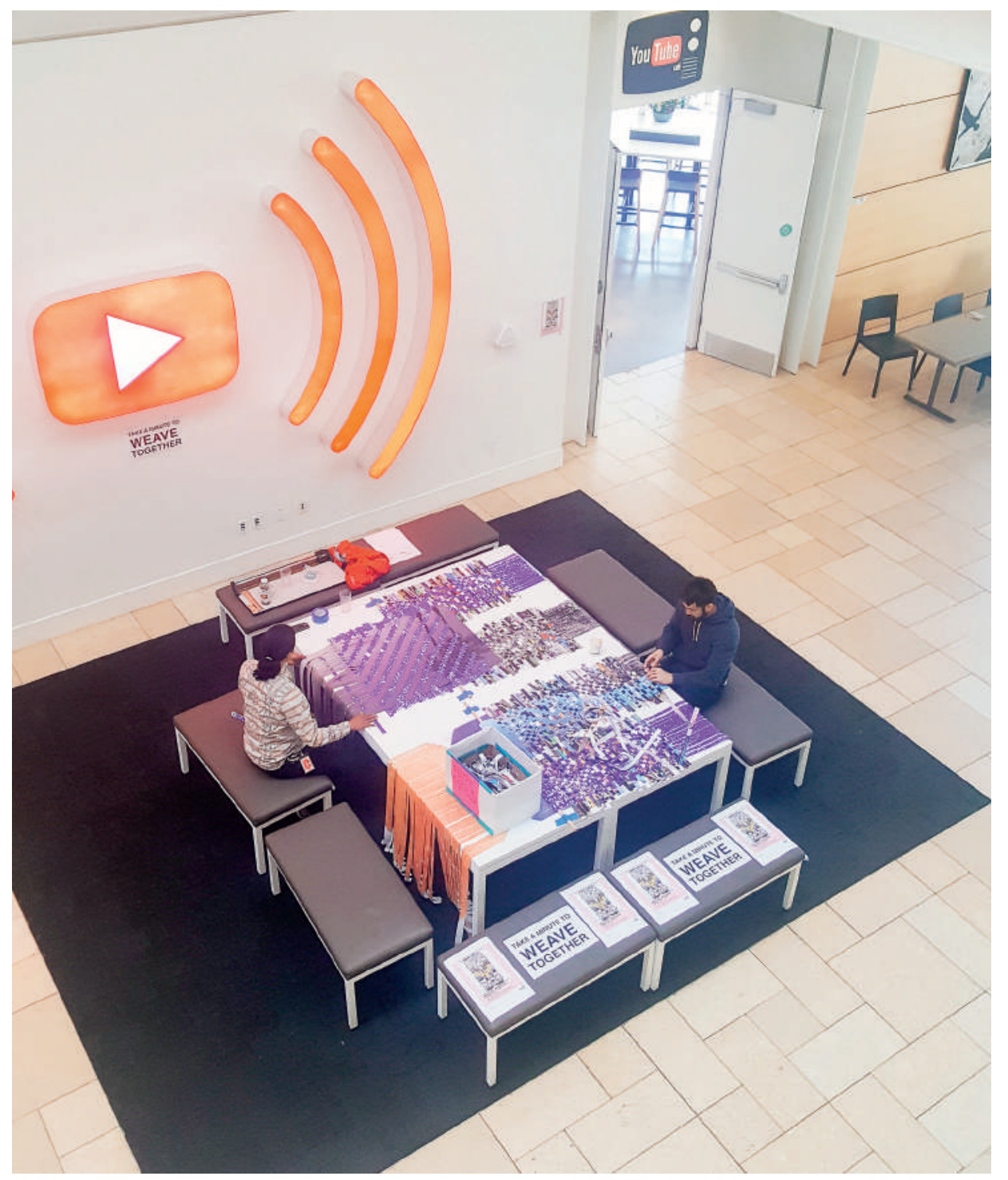

89| The Journal of Public Space, 3 (2), 2018 | ISSN 2206-9658 
Investing in Spaces: Luxury, Benevolence or Business?

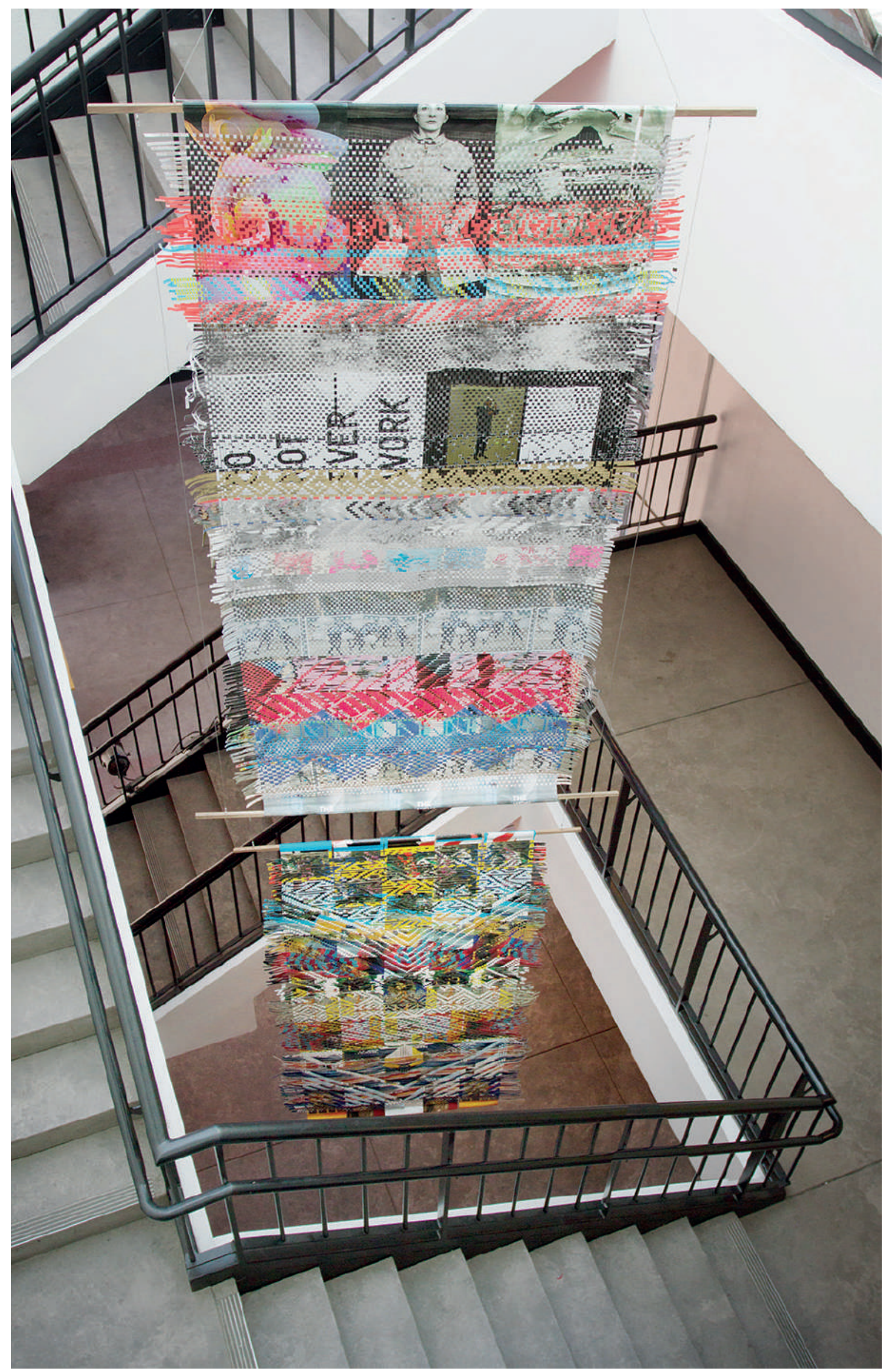

90 | The Journal of Public Space, 3 (2), 2018 | ISSN 2206-9658

City Space Architecture / UN-Habitat 
The selected artist, Miguel Arzabe is a San Francisco-based visual artist who works across media, including painting, video, and paper weaving.

Arzabe's work has been featured in such festivals as Hors Pistes (Centre Pompidou, Paris) and the Festival du Nouveau Cinéma (Montreal); and in museums and galleries including RM Projects (Auckland), FIFI Projects (Mexico City), Marylhurst University (Oregon), and Berkeley Art Museum.

The engagement scope included the following guidelines:

- Create conversations about diversity and inclusion and how team members experience them at YOUTUBE

- Guide a collaborative process where team members physically contribute to the making of the communal weaving

- Create an authentic social environment where team members can relax.

Working with Arzabe, limeSHIFT was able to design a process where the community could engage in two ways: first, members could submit photos online via the prompt: "Share a picture of yourself that makes you smile." These images were then printed.

Second, members could use the allocated common space to work together weaving the images together over a period of a week.

\section{After the week of collaboration one team member shared:}

"Creating this weaving mural with Miguel was a real opportunity to use my time and my hands in a delightfully unusual and dynamic way."

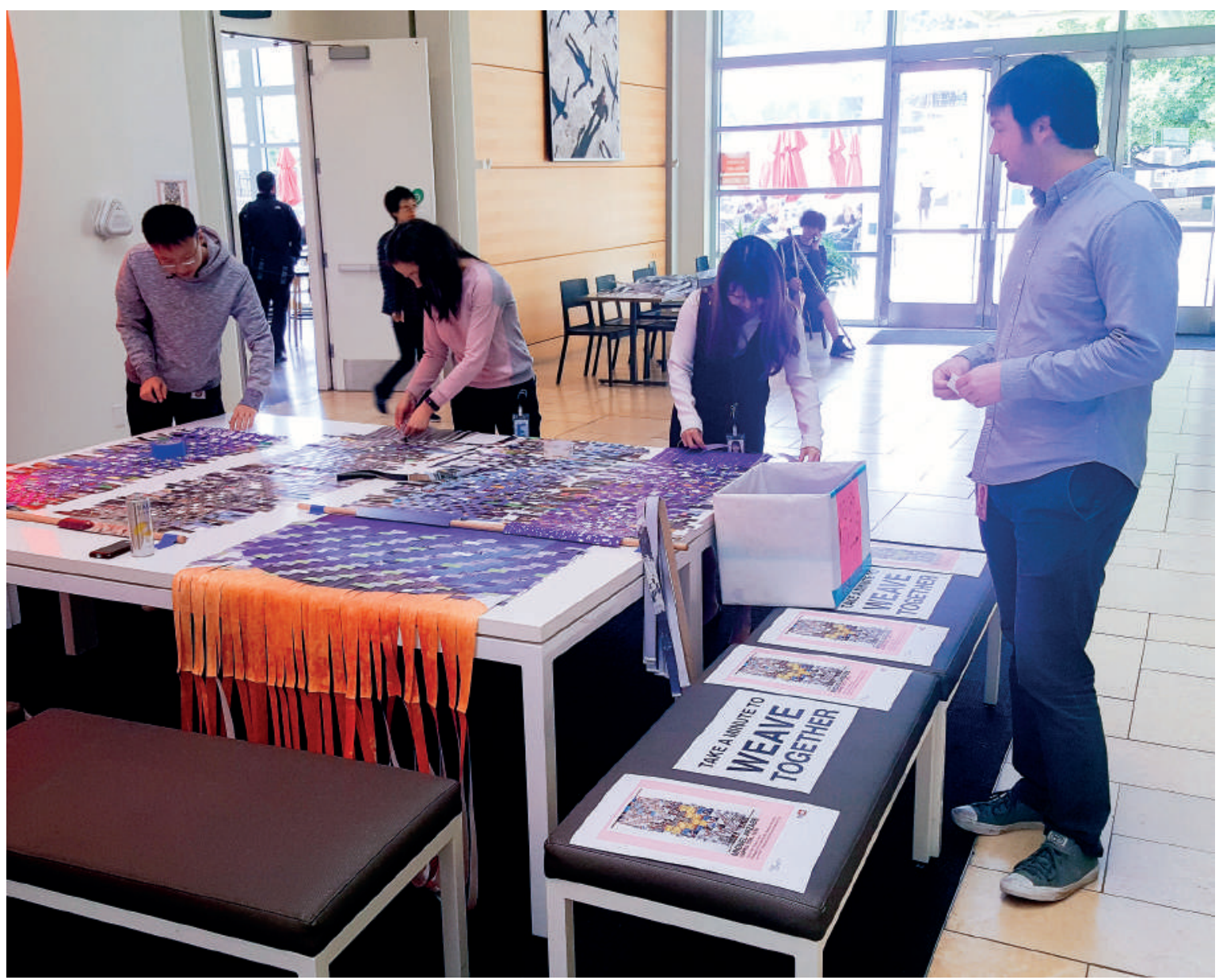

9I | The Journal of Public Space, 3 (2), 2018 | ISSN 2206-9658 City Space Architecture / UN-Habitat 
Investing in Spaces: Luxury, Benevolence or Business?
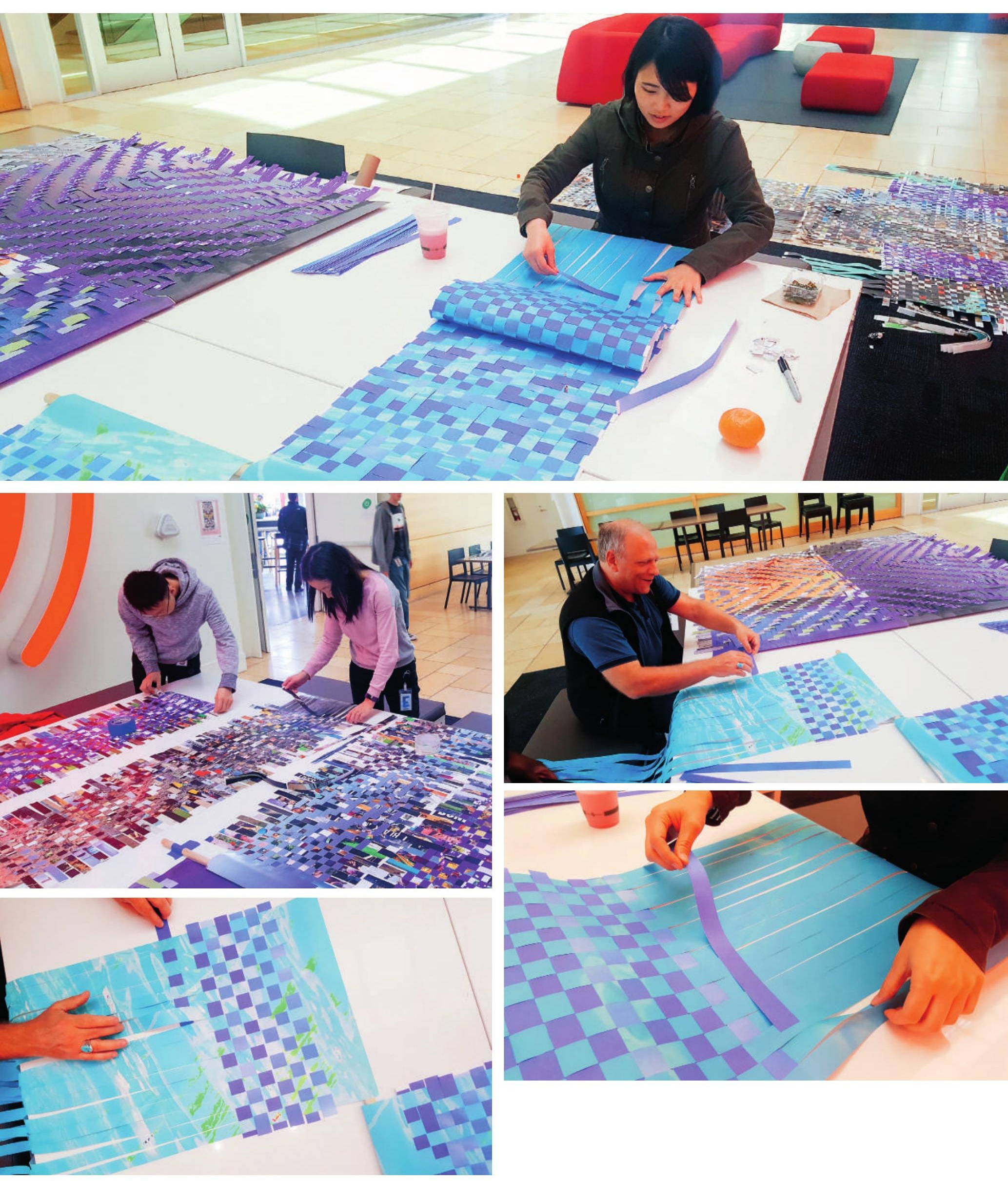

92 | The Journal of Public Space, 3 (2), 2018 | ISSN 2206-9658

City Space Architecture / UN-Habitat 


\section{Colour in Faith}

Client: Public-Private Partnership between a paint company, Sadolin Paints (now Plascon), local Government and civil society organizations (primarily religious, activist or artistic) Artist:Yazmany Arboleda

In 2016, Colour in Faith, a project of inCOMMONS, invited religious communities to paint their sacred spaces in "optimistic yellow." Colour in Faith attempts to reclaim, revive, and reunite communities in Nairobi materially and socially following the series of terrorist attacks and ethnic clashes. Three churches and one mosque were painted in the neighborhood of Kibera, before the project moved to other neighborhoods creating a movement of neighborhoods invested in solidarity.

Colour in Faith project in Kibera is a testimony to reimagine the luxury of benevolence as investment in local expressions and meaning of work, labour, and well-being. In discussing the with pastor Onesmus from the Pentecostal Assemblies of God (PAG) Makina, he expressed the notion of belonging, but also refuge, safety, and acceptance that the symbol of yellow offers to the community. He offers:

"When you see this colour, which means that we are together. So we are together, so in case of anything you can just run, when you are Muslim, when you are Christian, you can just run for safety in that place. So you can see there's a mosque down there, it was painted yellow. There's another church that was also painted yellow". (6 February 2018, Makina, Kibera) Although Onesmus only echoes one perspective, he repeats often that "peace prevails" when people in Kibera feel safe to do the ordinary tasks of the day.

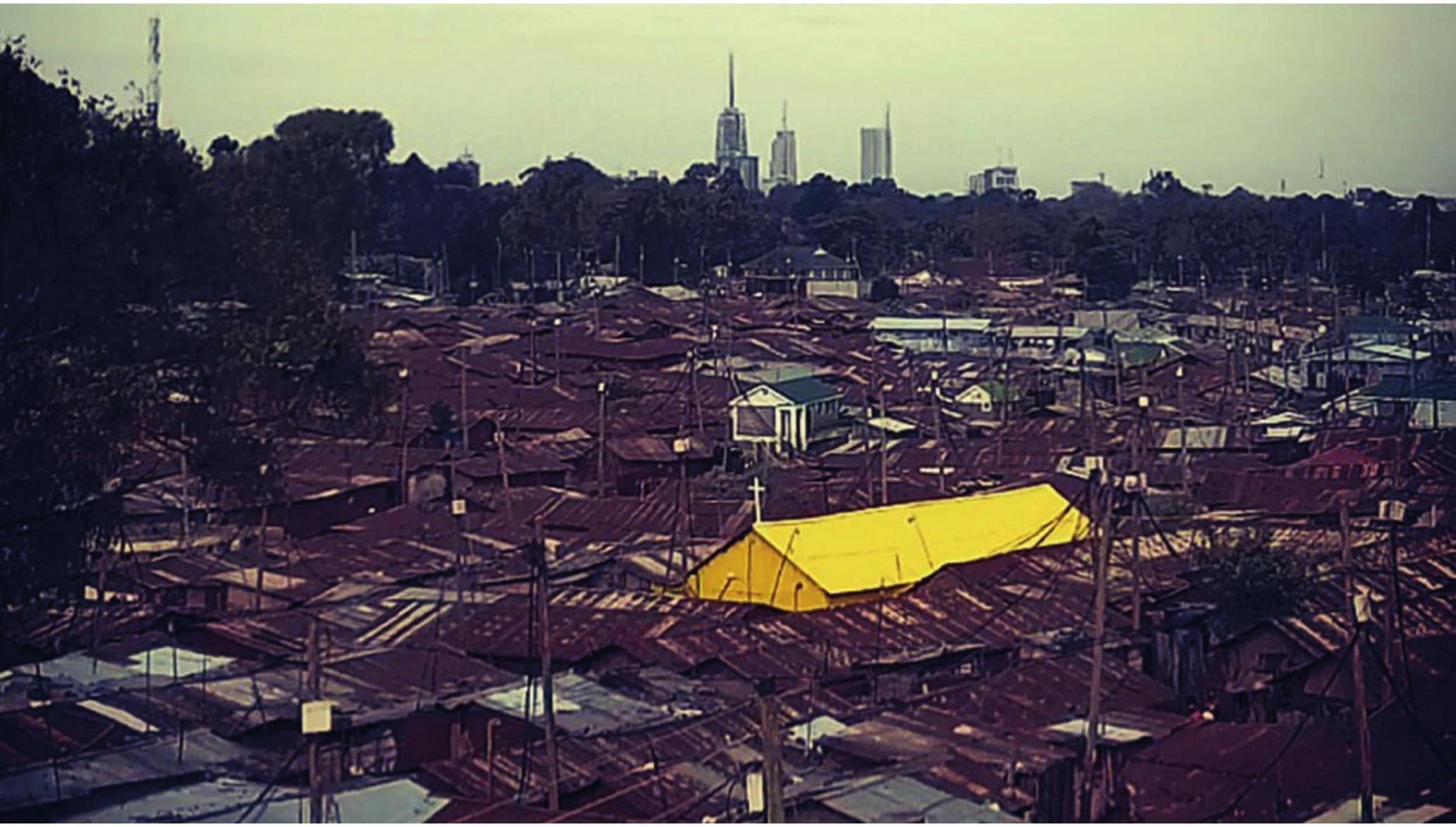

93 | The Journal of Public Space, 3 (2), 2018 | ISSN 2206-9658 City Space Architecture / UN-Habitat 

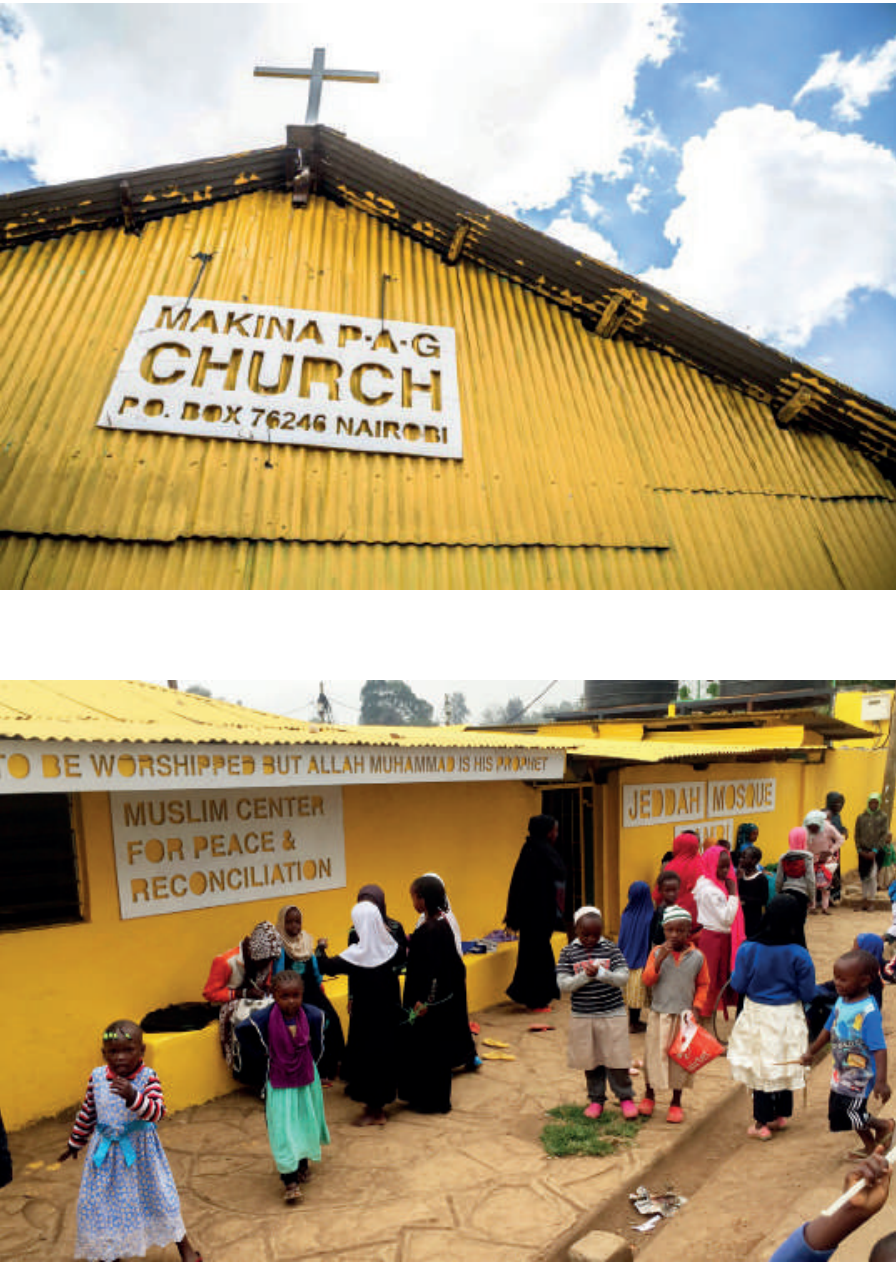

Following Onesmus, if people in Kibera can anticipate that the street is safe for jerrycans to arrive on time, for individuals to attend morning prayers and for children to attend school - then the women selling chapati and the matatu drivers can secure a livelihood for that day. In this way, sacred spaces of worship that were painted yellow - mosques and churches - became a catalyst and symbol of getting to work. It gestured a commitment by the community that the social fabric and economic prosperity of place and people are mutual aspects of wellbeing that requires investment through material gestures - such as paint - to sustain the socio-economic character of Kibera and its people. Colour and paint are small investments in the social values and notions of community in a dynamic workplace, place of worship and dwelling that results not only in higher employee and client engagement, but in stronger social ties.

The Colour in Faith project in Kibera highlights that social and economic aspects are both investments that can yield successful returns to place, people, and business.

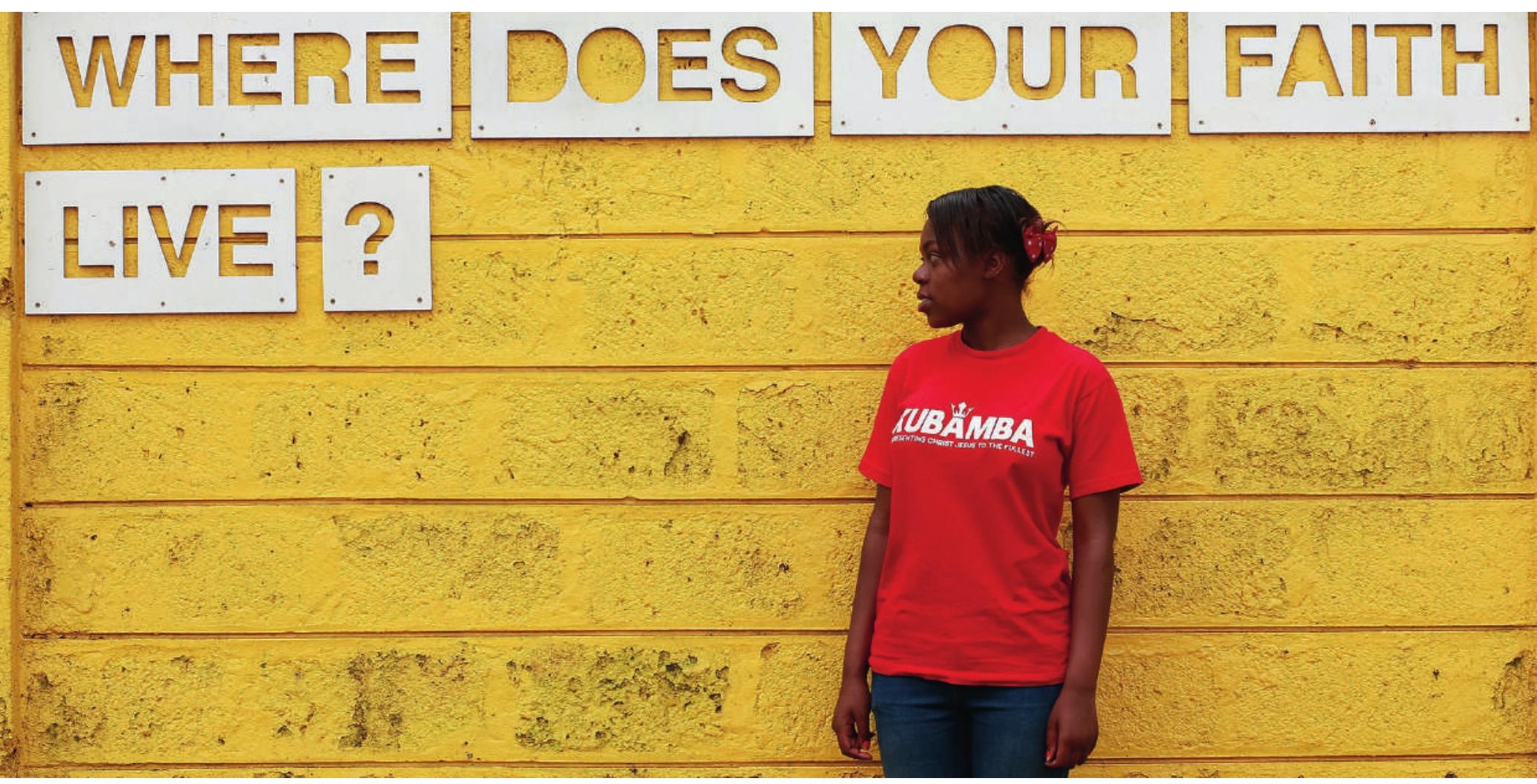

95 | The Journal of Public Space, 3 (2), 2018 | ISSN 2206-9658 City Space Architecture / UN-Habitat 
Investing in Spaces: Luxury, Benevolence or Business?
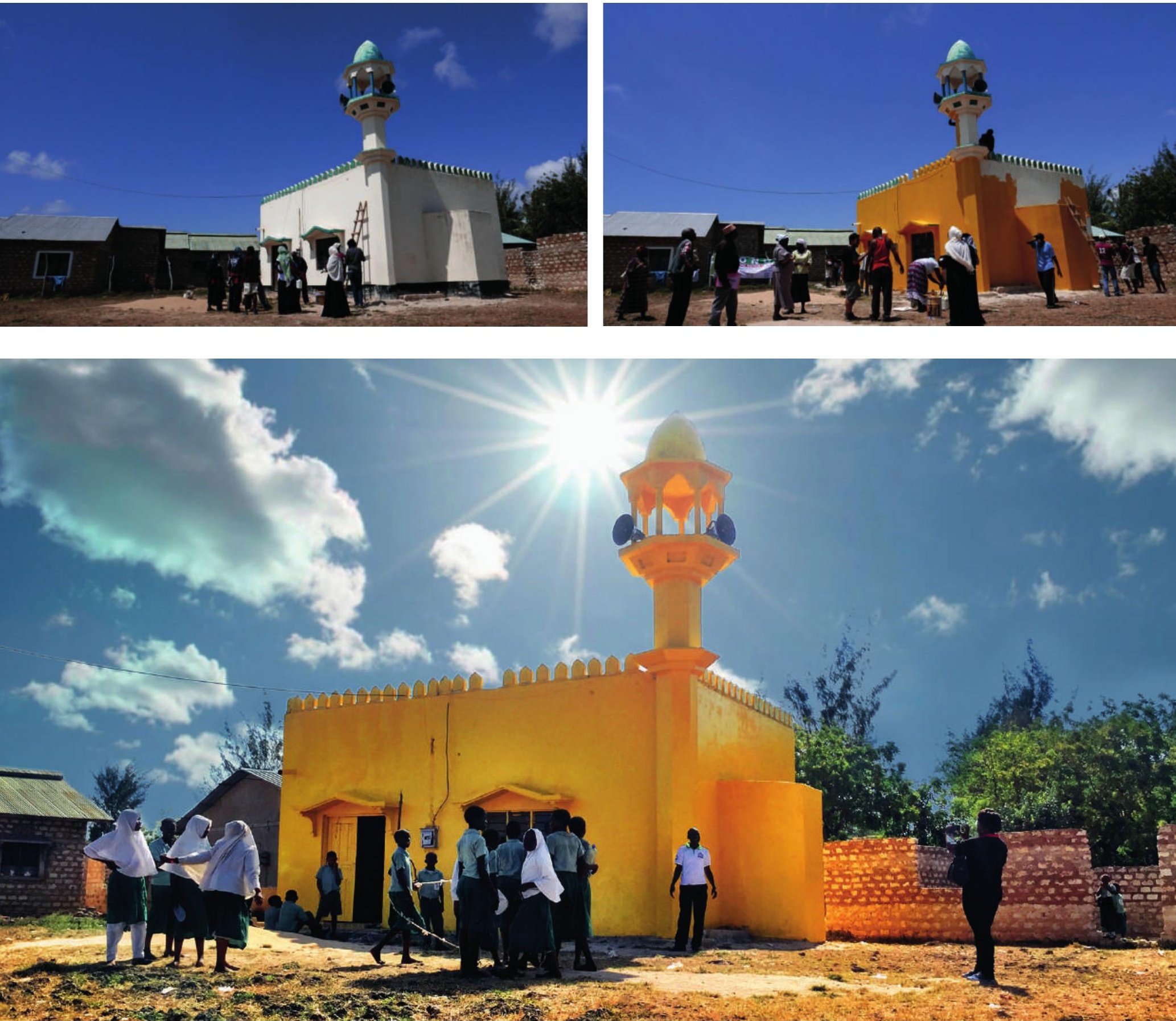

96 | The Journal of Public Space, 3 (2), 2018 | ISSN 2206-9658

City Space Architecture / UN-Habitat 